\title{
Failure of tropisetron to inhibit jejunal water and electrolyte secretion induced by 5-hydroxytryptamine in healthy volunteers
}

\author{
L K Munck, O Eskerod, M B Hansen, K Bukhave, J Rask-Madsen
}

\begin{abstract}
The effects of the 5-hydroxytryptamine $\left(5-H_{3}\right)$ receptor antagonist, ICS 205-930 (tropisetron), on basal and 5-HT induced jejunal secretion of water and electrolytes were examined using a double blind, randomised crossover design. In seven healthy volunteers steady state perfusions of the proximal jejunum were performed twice with the Loc-IGut tube after 5+5 mg ICS 205-930 or placebo capsules were given. After equilibration for $\mathbf{6 0}$ minutes and completion of a 120 minute basal period $5-\mathrm{HT}(10 \mu \mathrm{g} / \mathrm{kg} \times \mathrm{min}$ intravenously) was infused for 120 minutes. Net water absorption (mean (SEM)) in the basal period was 0.55 $(0.84) \mathrm{ml} / \mathrm{cm} \times \mathrm{h}$ and $0.74(0.72) \mathrm{ml} / \mathrm{cm} \times \mathrm{h}$ after placebo and ICS 205-930, respectively ( $p>0.05$ ). Infusion of 5-HT caused significant net secretion of water after placebo $(2.05(0.58)$ $\mathrm{ml} / \mathrm{cm} \times \mathrm{h} ; \mathrm{p}<0.02)$ as well as ICS 205-930 (2.60 (0.89) $\mathrm{ml} / \mathrm{cm} \times \mathrm{h} ; \mathrm{p}<0.05)$. As ICS 205930 excerted no effects on either basal or 5-HT induced water and electrolyte transport in the intact human jejunum the compound is probably not efficacious as an anti-secretory drug in patients with 5-HT induced diarrhoea.
\end{abstract}

(Gut 1994; 35: 637-640)

Numerous in vivo studies have shown that exogenous 5-hydroxytryptamine (5-HT) elicits secretion of chloride and water in the small intestine of rodents, ${ }^{1-3}$ cats, ${ }^{4}$ dogs, ${ }^{5}$ and pigs (unpublished data) as well as in the human small intestine. ${ }^{6}$ Jejunal secretion elicited by bacterial toxins, such as cholera toxin ${ }^{7-9}$ and Escherichia coli heat stable enterotoxin, ${ }^{10}$ by Entamoeba histolytica, ${ }^{11}$ and by antigens in sensitised animals $^{12}{ }^{13}$ is mediated, in part at least, by local release of 5-HT from enterochromaffine cells ${ }^{7}$ and immune cells, such as mast cells and phagocytes in the lamina propria. ${ }^{13}$ These cells play an important part in intestinal secretion through the release of prostaglandins ${ }^{13-15}$ by stimulation of the enterocyte $\mathrm{e}^{21316-18}$ or activation of neural reflex pathways..$^{14} 18$

More specifically, $5-\mathrm{HT}_{3}$ receptors have been implicated in the in vitro secretory response to both exogenous $5-\mathrm{HT}^{19}{ }^{20}$ and the $5-\mathrm{HT}_{3}$ receptor antagonist, ICS 205-930 (tropisetron), ${ }^{21}$ which inhibits in a dose dependent manner part of the jejunal water secretion occurring in rodents in response to $5-\mathrm{HT},{ }^{49}$ cholera toxin, ${ }^{4922}$ and Escherichia coli heat stable enterotoxin. ${ }^{10}$ Furthermore, abnormally high plasma concentrations of 5-HT ${ }^{23}$ and luminal jejunal release of prostaglandin $\mathrm{E}_{2}^{24}$ are associated with profuse diarrhoea. Thus, case reports have provided evidence that 5-HT receptor antagonists, such as ICS $205-930,{ }^{25}$ reduce the diarrhoeal volume in these patients, while high doses of ICS 205-930 alone acts as a secretagogue in the pig (unpublished data) and in combination with ketanserin increases cholera toxin induced jejunal water secretion in humans (unpublished data).

The purpose of this study was to examine the effects of ICS 205-930 on basal and 5-HT induced intestinal water and electrolyte transport in the human small intestine. Steady state perfusions of jejunum were performed in healthy volunteers using a randomised, double blind, crossover design.

\section{PARTICIPANTS AND SAFETY MEASUREMENTS}

Seven healthy male volunteers (median age 22 years, range 20-26) not receiving any treatment consented to the study protocol, which was approved by the regional ethical committee and the Danish National Health Service. All subjects were seen before inclusion for clinical assessment, electrocardiography, and laboratory screening (haemoglobin and packed cell volume; red cell, platelet and, leucocyte counts; plasma concentrations of creatine, sodium, and potassium; and activities of aspartate aminotransferase and alkaline phosphatase.) Laboratory tests were repeated at the end of each perfusion.

\section{EXPERIMENTAL DESIGN}

The study was carried out in a randomised, double blind, crossover design. Each participant had two jejunal perfusions with an interval of at least one week. Either placebo capsules or $5 \mathrm{mg}$ capsules of ICS 205-930 were given orally 12 hours and one hour before jejunal intubation.

\section{SEGMENTAL JEJUNAL PERFUSION}

After an overnight fast the Loc-I-Gut tube (Kabi Pharmacia, Uppsala, Sweden) was inserted orally. ${ }^{26} \mathrm{~A}$ guidewire was used for intubation and the position of the tube controlled by fluoroscopy. Proximal to a distal tungsten weight two inflatable latex balloons were placed $10 \mathrm{~cm}$ apart. The proximal balloon was placed at the ligament of Treitz and both balloons inflated with 35-40 $\mathrm{ml}$ of air. These volumes were adjusted during the perfusion and always at the start of 5-HT infusion to minimise leakage from the closed study segment. The volumes were, therefore, kept as high as possible, that is $1-2 \mathrm{ml}$ less than the volume that elicited abdominal discomfort.

The closed jejunal segment was perfused at $3 \mathrm{ml} / \mathrm{min}$ (LKB 2115 Multiperpex Pump, 
Bromma, Sweden). The composition in $\mathrm{mmol} / \mathrm{l}$ of the isotonic perfusion solution was: $\mathrm{Na}^{+} 145$, $\mathrm{K}^{+} 5, \mathrm{Cl}^{-} 140$, and $\mathrm{HCO}_{3}{ }^{-} 10 .{ }^{51} \mathrm{Cr}$-EDTA (15 $\mu \mathrm{Ci} / \mathrm{l}$ ) was added as a non-absorbable marker. Aspiration was by gravity drainage from ports next to the balloons. The aspirates were collected in 20 minute periods and immediately frozen to $-20^{\circ} \mathrm{C}$ until analysis. The volume of the study segment was about $80 \mathrm{ml} .{ }^{26}$

A second double lumen tube was positioned in the antrum of the stomach for aspiration of gastric juice. Phenol red $(50 \mathrm{mg} / \mathrm{l} ; 154 \mathrm{mM}$ $\mathrm{NaCl}$ ) was infused at a rate of $1 \mathrm{ml} / \mathrm{min}$ into the stomach and analysed in the effluents from the closed jejunal segment to rule out leakage.

After a 60 minute equilibration period, during which the closed jejunal segment was emptied for mucus, as judged from the appearance of clear aspirates, samples were collected in consecutive 20 minute periods. Both during the equilibration period and the control period (120 minutes) isotonic saline was infused intravenously at a rate of $50 \mathrm{ml} / \mathrm{h}$, when the infusion solution was changed to 5-HT (5-hydroxytryptamine creatinine sulphate (Serva, Heidelberg, Germany) dissolved in isotonic saline $(10 \mu \mathrm{g} /$ $\mathrm{kg} \times \min , 50 \mathrm{ml} / \mathrm{h}$ intravenously) for 120 minutes.

\section{ANALYTICAL PROCEDURES}

Sodium and potassium were determined by flame photometry (FLM 2, Radiometer, Copenhagen, Denmark) and chloride was measured in a chloride metre (CMT 10, Radiometer). ${ }^{51} \mathrm{Cr}$ activity was measured by gammaspectrometry (model 1185, Searle Nuclear Chicago Division, Chicago, USA). Phenol red was measured

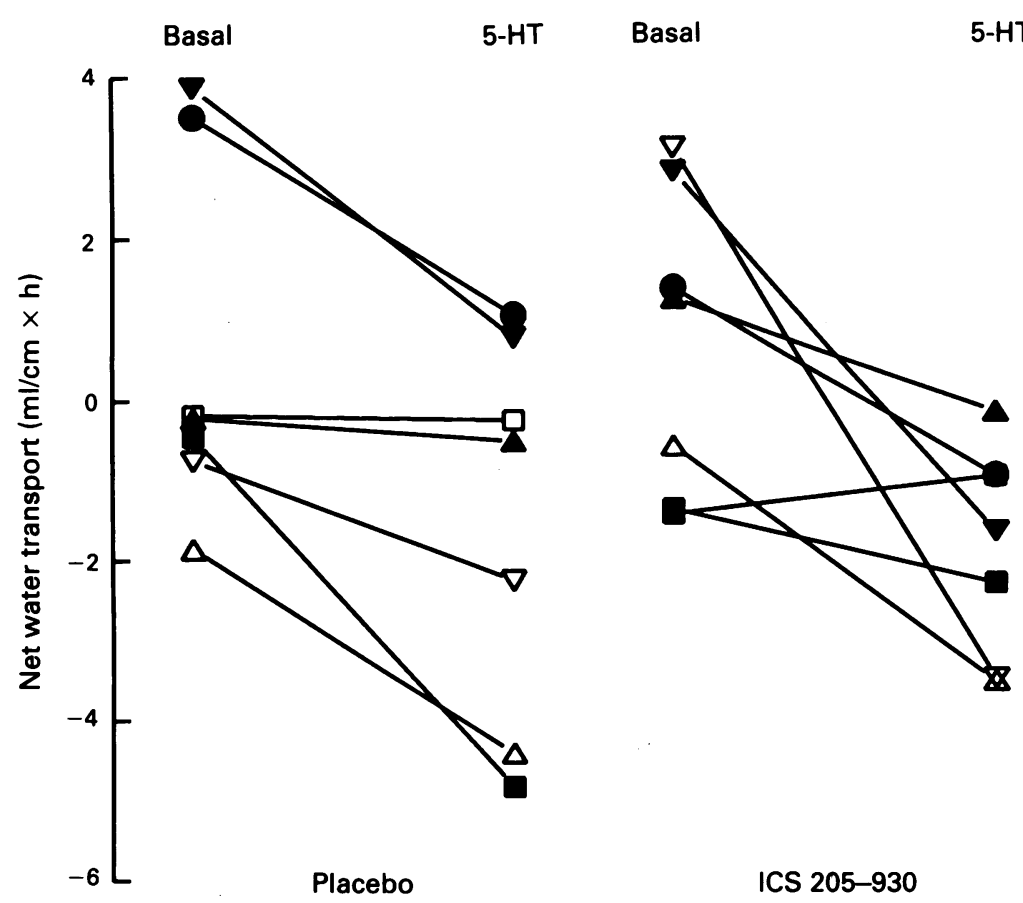

Figure 1: Effect of placebo or $10 \mathrm{mg}$ ICS 205-930 given orally on net water transport during control conditions (basal) and in response to 5-hydroxytryptamine $(5-H T)(10 \mu \mathrm{g} / \mathrm{kg} \times \mathrm{min}$ intravenously) in the proximal jejunum of seven healthy volunteers subjected to jejunal perfusion in a randomised, double blind, crossover design. A positive sign denotes net water absorption and a negative sign net water secretion. spectrophotometrically at $560 \mathrm{~nm}$ after alkalisation ( $\mathrm{pH} \mathrm{11)}$ with a $\mathrm{Na}_{3} \mathrm{PO}_{4}$ buffer.

\section{DETERMINATION OF WATER AND ELECTROLYTE}

TRANSPORT

Net water and electrolyte transport rates were determined as described by Knutson et $\mathrm{l}^{26}$ and expressed as $\mathrm{ml} / \mathrm{cm} \times \mathrm{h}$ and $\mathrm{mmol} / \mathrm{cm} \times \mathrm{h}$, respectively. Net absorption was shown by a positive sign and net secretion by a negative sign.

\section{STATISTICAL ANALYSES}

All results are given as means with standard errors (SEM). To discover if analysis of variance could be applied the results were tested for carryover and period effects on treatment outcomes using Student's $t$ test. This was done on the assumption that there were no residual effects. Pairs of group means were tested by one way analysis of variance and Duncan's multiple range test. Probability values less than 0.05 (two sided test) were considered significant.

\section{Results}

DESIGN

According to the protocol, active and placebo periods should be defined in each subject by the investigators from the change, if any, in net water transport rates calculated before breaking the code. Active or placebo periods were correctly defined only in four cases, suggesting that ICS 205-930 had no clinically relevant influence on water transport. Pairs of group means were tested by one way analysis of variance, because no statistically significant carryover effect $(p>0.35)$ or period effect $(p>0.61)$ was detected. The contamination by phenol red did not exceed $0 \cdot 1 \%$ in any aspirate analysed. The recovery of ${ }^{51} \mathrm{Cr}$-EDTA was $99 \cdot 7 \%(0 \cdot 8 \%)$ $(n=16)$, showing that the test segment was effectively isolated.

\section{NET WATER AND ELECTROLYTE TRANSPORT}

Net water transport rates (Figs 1 and 2) were insignificantly $(\mathrm{p}>0.05)$ different from zero during basal periods, both after placebo $(0.55$ $(0.84) \mathrm{ml} / \mathrm{cm} \times \mathrm{h})$ and ICS 205-930 (0.74 (0.72) $\mathrm{ml} / \mathrm{cm} \times \mathrm{h}$ ) was given. Subsequently, pretreatment with ICS 205-930 caused no change in basal net water absorption compared with placebo (Figs 1 and 2). Net secretion of water in response to 5-HT infusion was seen in all subjects who had received placebo capsules $(2.05(0.58) \mathrm{ml} / \mathrm{cm} \times \mathrm{h}$; $\mathrm{p}<0.02)$ and in all but one subject after ICS 205930 capsules $(2.60(0.89) \mathrm{ml} / \mathrm{cm} \times \mathrm{h} ; \mathrm{p}<0.05)$ (Figs 1 and 2), but there was no difference $(\mathrm{p}>0.05)$ in secretory response between active and inactive treatment.

Also net absorption of sodium, potassium, and chloride was insignificantly $(\mathrm{p}>0.05)$ different from zero during basal periods after placebo $(18 \cdot 3(24 \cdot 6), 1 \cdot 1(0.7)$, and $5 \cdot 5(19 \cdot 3) \mathrm{mmol} / \mathrm{cm} \times$ h) and ICS 205-930 $(21 \cdot 1(16 \cdot 2), 1 \cdot 1(0 \cdot 5)$, and $11 \cdot 7(15 \cdot 3) \mathrm{mmol} / \mathrm{cm} \times \mathrm{h})$, respectively. The 5-HT induced secretion of sodium, potassium, 


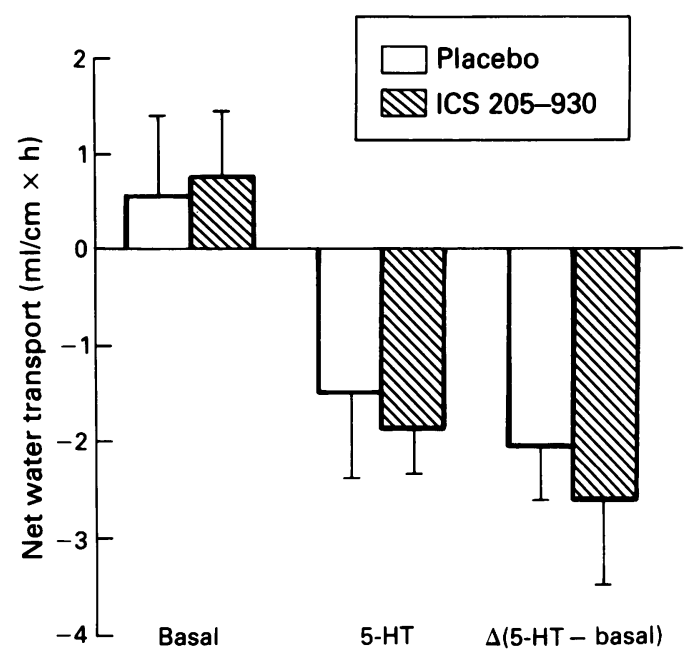

Figure 2: Net water transport rates in the human proximal jejunum during control conditions (basal) and in response to 5-hydroxytryptamine (5-HT) after placebo or $10 \mathrm{mg}$ ICS 205930 given orally. Net water transport rates during control conditions were unchanged after ICS 205-930 $(p=0.82)$. The secretory responses $\Delta(5-H T-$ basal $)$ after placebo $(p<0.02)$ and ICS 205-930 ( $p<0.03)$, respectively, were insignificantly different from each other $(p>0 \cdot 6)$. A positive sign denotes net absorption and a negative sign net secretion.

and chloride was not changed $(\mathrm{p}>0.05)$ by ICS 205-930 (Fig 3).

\section{ADVERSE EVENTS}

No adverse events from treatment with ICS 205930 or placebo were reported and no abnormalities or significant differences in laboratory screening values were seen before or after the study, respectively. The intravenous infusion of 5-HT caused pain at the infusion site and vasodilation. Minor oedema of the hands and flushing were seen in two cases. Most subjects reported nausea and abdominal discomfort, which was relieved by withdrawing a few $\mathrm{ml}$ of air from the balloons. All symptoms disappeared immediately after the 5-HT infusion was stopped. No effects on blood pressure or heart rate were registered.

\section{Discussion}

Intestinal water and electrolyte transport is controlled by the enteric nervous system, comprising intrinsic and extrinsic neurons, in addition to neuroendocrine cells, hormones, bacterial enterotoxins, and the immune system, all of which are anatomically and functionally intermingled. ${ }^{13-15}$ The neurotransmitter, $5-\mathrm{HT}$, is present predominantly in the enterochromaffine cells along the entire small intestine, but a minor part is found in the myenteric plexus and in the mast cells situated in the lamina propria. ${ }^{13}$ The 5 -HT induced, calcium dependent ${ }^{12}$ secretion is the result of inhibition of electroneutral sodium chloride absorption and stimulation of chloride secretion $^{12+}$ and is independent of changes in intestinal blood flow or permeability.

In this study we used a glucose free perfusion solution to permit comparison with previously published data on 5-HT induced jejunal secretion in humans. ${ }^{6}$ The results confirm that exogenous 5-HT induces jejunal secretion of water and electrolytes, as previously shown in vivo in various experimental animal models ${ }^{1-5}$ and in humans. ${ }^{6}$ The results also show that $10 \mathrm{mg}$ of ICS 205-930 (tropisetron) given orally has no effect on either basal water and electrolyte transport or 5-HT induced secretion. In a model of human secretory diarrhoea, in which $6.25 \mu \mathrm{g}$ cholera toxin given intrajejunally induced a secretory response of the same magnitude as seen in our study, ketanserin given parenterally and ICS 205-930 in combination enhanced the secretory effects of cholera toxin, while ICS 205-930 had no effect on basal water transport (unpublished data). In addition, ICS 205-930 failed to inhibit the secretory effects of cholera toxin in the pig small intestine in vivo and induced secretion at high rates (unpublished data).

Our results as well as those of others seen in pigs and in humans are not comparable with those obtained in vivo in rodents, ${ }^{4}{ }^{1022}$ because higher doses of the 5-HT receptor antagonists were given intravenously in the latter studies. In this study ICS $205-930$ was given 12 hours and one hour before the experiment to ensure absorption and stable plasma concentrations of the drug. The dose is equivalent to that given intravenously by Eherer et al (unpublished data) who saw no effect on net water absorption during control periods and, contrary with what has been seen in rodent experiments, an enhancement rather than inhibition of cholera toxin induced secretion by ICS 205-930. Thus, the lack of effect on basal and 5-HT stimulated water and electrolyte transport is probably not explained by insufficient absorption of the drug. The optimum therapeutic dose for prevention of nausea and vomiting associated with chemotherapy is $5 \mathrm{mg} .{ }^{22}$ It should also be noted that the risk of overlooking a true effect of ICS 205-930

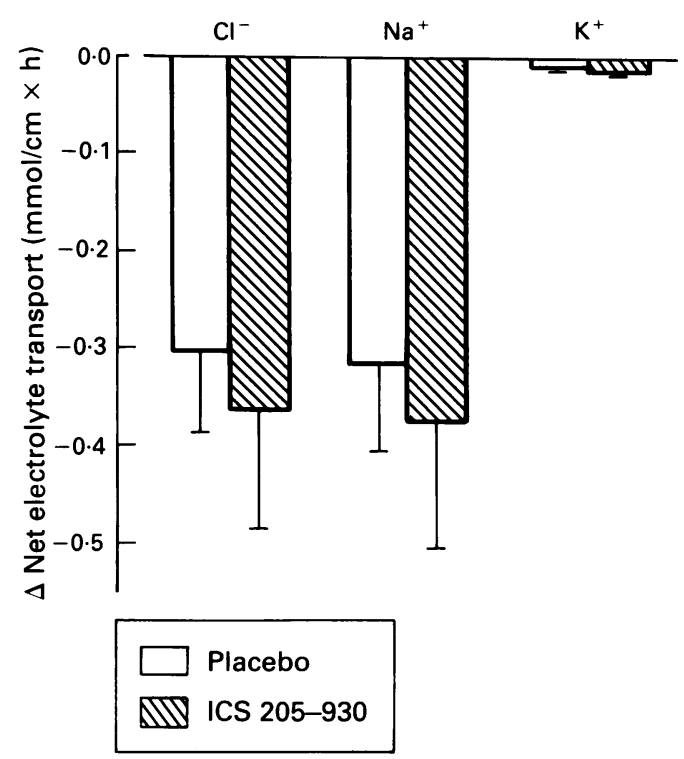

Figure 3: The response in net electrolyte transport elicited by 5-hydroxytryptamine in the human proximal jejunum illustrated by the means of differences between basal and stimulated periods after placebo and $10 \mathrm{mg}$ ICS $205-930$ given orally. The mean secretory responses were unchanged after ICS 205-930 compared with placebo periods ( $p>0.05)$. $A$ positive sign denotes net absorption and a negative sign net secretion. 
on net water transport - that is, type II error, exceeding $1.5 \mathrm{SD}$ was less than $20 \%$. Thus, the species differences seen between rodents and humans are probably not explained by differences in dose or route of administration.

Net absorption of water and electrolytes is the most common finding in perfusion studies of the human small intestine using the triple lumen technique $^{6}$ or the double lumen technique with a proximal occluding balloon (unpublished data). In this study net water absorption was minimal and insignificantly different from zero ( $p>0.05)$. Minimal net secretion of water occurred in several subjects during basal conditions, both after placebo and ICS 205-930 (Fig 1). This discrepancy between our previous study using the same perfusion solution, ${ }^{6}$ but the triple lumen technique, cannot be explained by the absence of glucose in the perfusate. It might be the result, however, of jejunal distension by occluding balloons, which has been shown to elicit net chloride secretion in rat colon. ${ }^{27}$ On the other hand, distension of the normal human jejunum with a balloon did not interfere with intrinsic myoelectrical activity. ${ }^{28}$ As the perfusions were performed during 'steady state' conditions any influence of the distended balloons on basal intestinal secretion probably will not have obscured an anti-secretory effect of ICS 205-930, although it might have decreased the response seen with $5-\mathrm{HT}$.

Presently, we cannot explain the conflicting results of ICS 205-930 on water and electrolyte transport in the small intestine of rodents and humans. The results of this study emphasise the risk of drawing conclusions concerning drug actions in humans from findings made in rodent studies, but suggest that the investigational drug, ICS 205-930, is probably not efficacious as an anti-secretory drug in patients with diarrhoea.

This work was supported by a research grant from Sandoz Ltd, who also kindly provided ICS 205-930 and placebo capsules. Part of the work has been presented at XXXIInd International of the work has been presented at XXXIInd International Congress of the Intern
Glasgow, August 1993.

1 Hardcastle J, Hardcastle PT, Redfern JS. Action of 5 -hydroxytryptamine on intestinal ion transport in the rat. f Physiol 1981; 320: 41-55.

2 Beubler E, Bukhave K, Rask-Madsen J. Significance of calcium for the prostaglandin $E_{2}$-mediated secretory calcium for the prostaglandin $E_{2}$-mediated secretory
response to 5-hydroxytryptamine in the small intestine of the response to 5-hydroxytryptamine in the small in
rat in vivo. Gastroenterology 1986; 90: 1072-7.

3 Donowitz M, Tai Y-H, Asarkof N. Effect of serotonin on active electrolyte transport in rabbit ileum, gallbladder, and colon. Am F Physiol 1980; 239: G463-72.

4 Sjöqvist A, Cassuto J, Jodal M, Lundgren O. Actions of serotonin antagonists on cholera-toxin-induced intestina fluid secretion. Acta Physiol Scand 1992; 145: 229-37.
5 Zinner MJ, McFadden D, Sherlock D, Jaffa BM. Verapamil reversal of serotonin-induced jejunal secretion of water and electrolytes in awake dogs. Gastroenterology 1986; 90: 515-9.

6 Munck LK, Mertz-Nielsen A, Westh H, Bukhave K, Beuble E, Rask-Madsen J. Prostaglandin $\mathrm{E}_{2}$ is a mediator of 5-hydroxytryptamine induced water and electrolyte secretion in the human jejunum. Gut 1988; 29: 1337-41.

7 Nilsson O, Cassuto J, Larsson P-A, Jodal M, Lidberg P, Ahlman $\mathrm{H}$, et al. 5-Hydroxytryptamine and cholera secretion: a study in cats. Gut 1983; 24: 542-8.

8 Beubler E, Kollar G, Saria A, Bukhave K, Rask-Madsen J. Involvement of 5-hydroxytryptamine, prostaglandin $\mathrm{E}_{2}$, and cyclic adenosine monophosphate in cholera toxin induced fluid secretion in the small intestine of the rat in vivo. Gastroenterology 1989; 96: 368-76.

9 Beubler E, Horina G. 5- $\mathrm{HT}_{2}$ and $5-\mathrm{HT}_{3}$ receptor subtypes mediate cholera toxin-induced intestinal fluid secretion in the rat. Gastroenterology 1990; 99: 83-9.

10 Beubler E, Badhri P, Schirgi-Degen A. 5-HT receptor antagonists and heat-stable Escherichia coli enterotoxin-induced effects in the rat. Eur $\mathcal{F}$ Pharmacol 1992; 219: 445-50.

11 McGowan K, Kane A, Asarkof N, Wicks J, Guerina V, Kellum J, et al. Entamoeba histolytica causes intestinal secretion: role of serotonin. Science 1983; 221: 762-4.

12 Crowe SE, Perdue MH. Gastrointestinal food hypersensitivity: basic mechanisms of pathophysiology. Gastroenterology 1992; 103: 1075-95.

13 Powel DW. Immunophysiology of intestinal electrolyte transport. In: Schultz SG, ed. Handbook of physiology, the gastrointestinal system IV. Rockville, MD: American Physiological Society, 1991: 591-641.

14 Bern MJ, Sturbaum CW, Karayalcin SS, Berschneider HM, Wachsman JT, Powel DW. Immune system control of rat and rabbit colonic electrolyte transport. Role of prostaglandins and enteric nervous system. $\mathcal{F}$ Clin Invest $1989 ; 83$; 1810-20.

15 Berschneider HM, Powell DW. Fibroblasts modulate intestinal secretory responses to inflammatory mediators. 7 Clin Invest 1992; 89: 484-9.

16 Misiewicz JJ, Waller SL, Kiley N, Horton EW. Effects of ora prostaglandin $\mathrm{E}_{1}$ on intestinal transit in man. Lancet $1969 ; \mathrm{i}$ : 648-51.

17 Sobhani I, Vidon N, Huchet B, Rambaud JC. Human jejunal secretion induced by prostaglandin $\mathrm{E}_{1}$ : a dose-response secretion induced by prostaglandin $E_{1}$ :
study. Brf Clin Pharmacol $1992 ; 31: 433-7$.

18 Brunsson I, Sjöqvist A, Jodal M, Lundgren O. Mechanisms underlying the small intestinal fluid secretion caused by arachidonic acid, prostaglandin $E_{1}$ and prostaglandin $E_{2}$ in the rat in vivo. Acta Physiol Scand 1987; 130: 633-42.

19 Hendriks R, Bornstein JC, Furness JB. Evidence for two type of 5-hydroxytryptamine receptor on secretomotor neuron of the guinea-pig ileum. Naunyn Schmiedebergs Arch Pharmacol 1989; 339: 409-14.

20 Cooke HJ, Wang Y-Z, Frieling T, Wood JD. Neural 5-hydroxytryptamine receptors regulate chloride secretion in guinea pig distal colon. Am 7 Physiol 1991; 261: G833-40.

21 de Bruijn KM. Tropisetron. A review of the clinical experience. Drugs 1992; 43 (suppl 3): 11-22.

22 Buchheit $\mathrm{K}-\mathrm{H}$. Inhibition of cholera toxin-induced intestinal secretion by the 5-HT receptor antagonist ICS 205-930. Naunyn Schmiedebergs Arch Pharmacol 1989; 339: 704-5.

23 Donowitz M, Binder HJ. Jejunal fluid and electrolyte secretion in carcinoid syndrome. Dig Dis 1975; 20: 1115-22.

24 Rask-Madsen J, Bukhave K, Beubler E. Influence on intestinal secretion of eicosanoids. F Intern Med 1990; 228 (suppl 732): 137-44.

25 Anderson JV, Coupe MO, Morris JA, Hodgson HJ, Bloom SR. Remission of symptoms in carcinoid syndrome with new 5-hydroxytryptamine $M$ receptor antagonist. $B M \mathcal{F}$ 1987; 294: 1129 .

26 Knutson L, Odlind B, Hällgren R. A new technique for segmental jejunal perfusion in man. Am 7 Gastroenterol 1989 84: 1278-84.

27 Itasaka S, Shiratori K, Takahashi T, Ishikawa M, Kaneko K, Suzuki Y. Stimulation of intramural secretory reflex by Suzuki Y. Stimulation of intramural secretory reflex by 1992; 263: G108-14.

28 Accarino AM, Azpiroz F, Malagelada J-R. Symptomatic responses to stimulation of sensory pathways in the human jejunum. Am $\mathcal{F}$ Physiol 1992; 263: G673-7. 